Pawel Szklarzyk ${ }^{1}$, Dorota Klimecka-Tatar ${ }^{2}$, Piotr Sygut ${ }^{3}$, Tomasz Lipiński ${ }^{4}$

\title{
QUALITY ASSESSMENT OF THE HOT-ROLLED PRODUCTS
}

\begin{abstract}
In 2013, global steel production reached a level of 1.548 million tons. This value indicates that, in the $21^{\text {st }}$ century, steel is still one of the most popular construction materials. In the steel works in Poland were produced 8.2 million tons of steel in 2013. A large share of steel is used for the production of hot-rolled plates for motor-car body. Steel products made in high temperature processes are used in virtually all sectors of industries. The hot-rolled plates for motor-car body should comply with the highest quality requirements. In a chapter are presented the results of research from the 12-month follow-up. To assess the level of nonconformity hot-rolled plates were used Pareto-Lorenz diagram. The results are the basis for the improvement of the production process hotrolled products.
\end{abstract}

Key words: hot-rolled products, Pareto-Lorenz diagram, steel company, TQM

\section{Quality as most important element during hot-rolled plates production process for motor-car body}

Quality is a concept of a philosophical ground. PLATON said: quality - (gr. poiotes, łac. qualitas) is a certain level of perfection. According to the standard PN-EN ISO 2000:2006, quality is defined as: degree to which a set of inherent characteristics fulfils requirements. The quality level of hot-rolled products depends on: wrong thickness, mechanical damage, shell.

Polish Standard PN-EN ISO 9000:2006 defines nonconformities as non-fulfilment of a requirement (PN-EN ISO 9000:2006).

\footnotetext{
${ }^{1}$ Mgr inż., Czestochowa University of Technology, Faculty of Management, Institute of Production Engineering, e-mail: szklarzyk.pawel@o2.pl

${ }^{2}$ Dr inż., Czestochowa University of Technology, Faculty of Management, Institute of Production Engineering, e-mail: klimt@ wip.pcz.pl

${ }^{3}$ Dr inż., Czestochowa University of Technology, Faculty of Management, Institute of Production Engineering, e-mail: piotr.sygut.wz@gmail.com

${ }^{4}$ Dr hab. inż., prof. UWM, Uniwersytet Warmińsko-Mazurski, Wydział Nauk Technicznych, Katedra Technologii Materiałów i Maszyn, e-mail: tomekl@uwm.edu.pl
} 
For the car companies the quality of products is crucial because it is one of the main factors influencing the degree of customer satisfaction. To meet the expectations of customers the car companies should look for new methods of improving quality. In order to apply appropriate improvement tools, it is necessary to identify nonconformities that affect the quality of the product.

\section{Experiment}

The assessment of the quality of the hot-rolled plates was carried out in one of the hot mill in Poland. The observation period was one calendar year. During the 12-month study period, collected data on emerging nonconformities and their quantitative presence. Research carried out for one grade of steel. The steel used for production of the plates belongs to a group of structural steels for cold forming. The investigation was carried out on S260NC steel. Chemical composition of the steel investigated is given in Table 1 (PN-EN 10149-3:2000, DOBRZAŃŚKI L. 2012).

Table 1. Chemical composition of steel S260NC [\%]

\begin{tabular}{|c|c|c|c|c|}
\hline STEEL GRADE & $\mathbf{C}$ & $\mathbf{M n}$ & $\mathbf{S i}$ & $\mathbf{P}$ \\
\hline \multirow{3}{*}{ S260NC } & 0.16 & 1.2 & 0.5 & 0.025 \\
\cline { 2 - 5 } & $\mathrm{S}$ & $\mathrm{Nb}$ & $\mathrm{V}$ & $\mathrm{Ti}$ \\
\cline { 2 - 5 } & 0.02 & 0.09 & 0.1 & 0.15 \\
\hline
\end{tabular}

Source: PN-EN 10149-3:2000, DOBRZAŃŚSI L. 2012 


\subsection{Identification of nonconformities during the hot-rolled plates production process}

For the assessment of nonconformities hot-rolled plates was used Pareto-Lorenz diagram.

Pareto-Lorenz diagram is one of the seven basic tools of quality management. It is based on an established empirical regularity that in nature, technology, human activity, usually $20 \div 30 \%$ of the causes decided by about $70 \div 80 \%$ impact (BORKOWSKI S. 2004). Distribution, Pareto - Lorenz can be used to present all phenomena and relationships that can be presented numerically and make a percentage. It serves, so he set out to give validity to factors causing the problem (BORKOWSKI S. 2004, BORKOWSKI S., ULEWICZ R. 2003, ULEWICZ R. 2009).

The nonconformities discovered during the research have been presented in the Table 2 .

Table 2. Types of nonconformities detected during the of the hot-rolled plates production process

\begin{tabular}{|c|c|}
\hline $\begin{array}{c}\text { Symbol of } \\
\text { nonconformities }\end{array}$ & Names of nonconformities \\
\hline N1 & Interruption of metal \\
\hline N2 & Other \\
\hline N3 & Bad thickness \\
\hline N4 & Pinchers \\
\hline N5 & Honeycomb blowholes \\
\hline N6 & Irregular dimensions \\
\hline N7 & Mechanical damages \\
\hline N8 & Overlap \\
\hline N9 & Shells \\
\hline N10 & Cockles (two sides) \\
\hline N11 & Cockles (one sides) \\
\hline N12 & Alligatoring \\
\hline
\end{tabular}

Source: own study 
Table 3 shows percentage share of nonconformities occurring during hot-rolled plate's production process in the first quarter of the year.

The data presented in Table 3 contains information about mass nonconforming plates $(\mathrm{Mg})$, and the percentages of each nonconforming plates.

Basing on data from the 4.3 Table the Pareto-Lorenz diagram was constructed (Fig. 1).

Based on the data from Table 4.3, it was found that in the first quarter year were produced $7794.07 \mathrm{Mg}$ of nonconforming products.

Table 3. Percentage share of nonconformities occurring during the production of hot-rolled plates in the first quarter of the year

\begin{tabular}{|c|c|c|}
\hline \multicolumn{3}{|c|}{ I QUARTER YEAR } \\
\hline $\begin{array}{c}\text { Symbol of } \\
\text { nonconformities }\end{array}$ & $\begin{array}{c}\text { Amount } \\
{[\mathrm{Mg}]}\end{array}$ & $\begin{array}{c}\text { The } \\
\text { percentage } \\
\text { share } \\
{[\%]}\end{array}$ \\
\hline$N_{1}$ & 1714.9 & 22.00 \\
\hline $\mathbf{N}_{3}$ & 1456.7 & 18.69 \\
\hline$N_{10}$ & 1292.3 & 16.58 \\
\hline $\mathrm{N}_{2}$ & 1181 & 15.15 \\
\hline $\mathbf{N}_{9}$ & 914.7 & 11.74 \\
\hline$N_{11}$ & 579.9 & 7.44 \\
\hline $\mathbf{N}_{7}$ & 240.7 & 3.09 \\
\hline $\mathbf{N}_{8}$ & 180.7 & 2.32 \\
\hline$N_{6}$ & 146.7 & 1.88 \\
\hline $\mathbf{N}_{4}$ & 73 & 0.94 \\
\hline $\mathbf{N}_{5}$ & 11.1 & 0.14 \\
\hline $\mathbf{N}_{12}$ & 2.36 & 0.03 \\
\hline$\Sigma$ & 7794.07 & 100 \\
\hline
\end{tabular}

Source: own study 


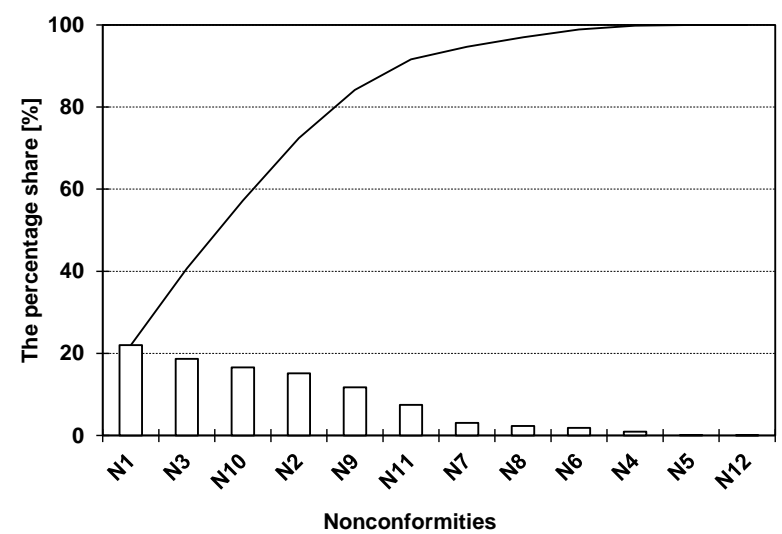

Fig. 1. The Pareto-Lorenz diagram for the nonconformities occurring during the production of hot-rolled plates $1^{\text {st }}$ quarter of the year.

Source: own study

Based on the Table 3 and Figure 1, it could be stated that for over $57.27 \%$ of all detected nonconformities are responsible only $25 \%$ types of nonconformities.

$57.27 \%$ of defects are connected with only three problems: interruption of metal, bad thickness and cockles (two sides) whereas the remaining types of defects are merely $42.73 \%$ in total of all defect.

Table 4 shows percentage share of nonconformities occurring during hot-rolled plates production process in the second quarter of the year.

The data presented in Table 4 contains information about mass nonconforming plates $(\mathrm{Mg})$, and the percentages of each nonconforming plates.

Based on the data from Table 4, it was found that in the second quarter year were produced $9554.65 \mathrm{Mg}$ of nonconforming products.

Basing on data from the 4 Table the Pareto-Lorenz diagram was constructed (Fig. 2). 
Table 4. Percentage share of nonconformities occurring during the production of hot-rolled plates in the second quarter of the year

\begin{tabular}{|c|c|c|}
\hline \multicolumn{3}{|c|}{ II QUARTER YEAR } \\
\hline $\begin{array}{c}\text { Symbol of } \\
\text { nonconformities }\end{array}$ & $\begin{array}{c}\text { Amount } \\
{[\mathbf{M g}]}\end{array}$ & $\begin{array}{c}\text { The } \\
\text { percentage } \\
\text { share } \\
{[\%]}\end{array}$ \\
\hline $\mathbf{N}_{\mathbf{1 0}}$ & 1938.5 & 20.02 \\
\hline $\mathbf{N}_{\mathbf{1}}$ & 1792.1 & 18.51 \\
\hline $\mathbf{N}_{\mathbf{2}}$ & 1653.4 & 17.08 \\
\hline $\mathbf{N}_{\mathbf{3}}$ & 1602.4 & 16.55 \\
\hline $\mathbf{N}_{\mathbf{9}}$ & 1097.6 & 11.34 \\
\hline $\mathbf{N}_{\mathbf{1 1}}$ & 985.8 & 10.18 \\
\hline $\mathbf{N}_{\mathbf{7}}$ & 216.6 & 2.24 \\
\hline $\mathbf{N}_{\mathbf{6}}$ & 176.0 & 1.82 \\
\hline $\mathbf{N}_{\mathbf{8}}$ & 126.5 & 1.31 \\
\hline $\mathbf{N}_{\mathbf{4}}$ & 80.3 & 0.83 \\
\hline $\mathbf{N}_{\mathbf{5}}$ & 8.88 & 0.09 \\
\hline $\mathbf{N}_{\mathbf{1 2}}$ & 3.07 & 0.03 \\
\hline & 9554.65 & 100 \\
\hline
\end{tabular}

Source: own study

Based on the Table 4 and Figure 2, it could be stated that for over $55.61 \%$ of all detected nonconformities are responsible only $25 \%$ types of nonconformities.

$55.61 \%$ of defects are connected with only three problems: cockles (two sides), interruption of metal and different whereas the remaining types of defects are merely $44.39 \%$ in total of all defects.

Table 5 shows percentage share of nonconformities occurring during hot-rolled plates production process in the third quarter of the year. 


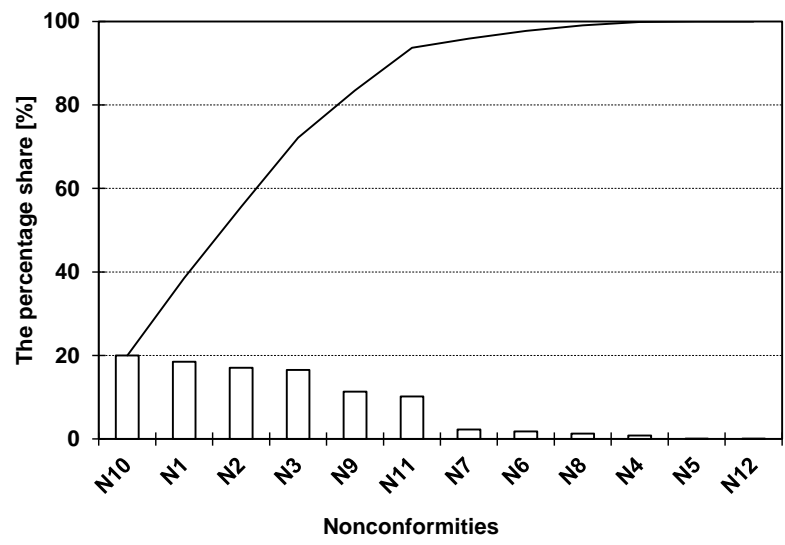

Fig. 2. The Pareto-Lorenz diagram for the nonconformities occurring during the production of hot-rolled plate $2^{\text {nd }}$ quarter of the year.

Source: own study

The data presented in Table 5 contains information about mass nonconforming plates $(\mathrm{Mg})$, and the percentages of each nonconforming plates.

Based on the data from Table 5, it was found that in the third quarter year were produced $8752.48 \mathrm{Mg}$ of nonconforming products.

Basing on data from the 5 Table the Pareto-Lorenz diagram was constructed (Fig. 2.3).

Based on the Table 5 and Figure 3, it could be stated that for over $64.32 \%$ of all detected nonconformities are responsible only $25 \%$ types of nonconformities. $64.32 \%$ of defects are connected with only three problems: Cockles (two sides), Interruption of metal, bad thickness whereas the remaining types of defects are merely $35.68 \%$ in total of all defects. 
Table 5. Percentage share of nonconformities occurring during the production of hot-rolled plates in the third quarter of the year

\begin{tabular}{|c|c|c|}
\hline \multicolumn{3}{|c|}{ III QUARTER } \\
\hline $\begin{array}{c}\text { Symbol of } \\
\text { nonconformities }\end{array}$ & $\begin{array}{c}\text { Amount } \\
{[\mathrm{Mg}]}\end{array}$ & $\begin{array}{c}\text { The } \\
\text { percentage } \\
\text { share } \\
{[\%]}\end{array}$ \\
\hline $\mathbf{N}_{10}$ & 2520 & 23.93 \\
\hline $\mathbf{N}_{1}$ & 2330 & 22.13 \\
\hline $\mathbf{N}_{3}$ & 1922.9 & 18.26 \\
\hline $\mathbf{N}_{2}$ & 1322.7 & 12.56 \\
\hline $\mathbf{N}_{9}$ & 987.87 & 9.38 \\
\hline$N_{11}$ & 788.7 & 7.49 \\
\hline $\mathbf{N}_{7}$ & 259.9 & 2.47 \\
\hline $\mathbf{N}_{6}$ & 176.0 & 1.67 \\
\hline $\mathbf{N}_{8}$ & 139.14 & 1.32 \\
\hline $\mathbf{N}_{4}$ & 68.26 & 0.65 \\
\hline $\mathbf{N}_{5}$ & 10.21 & 0.10 \\
\hline $\mathrm{N}_{12}$ & 3.37 & 0.03 \\
\hline$\sum$ & 8752.48 & 100 \\
\hline
\end{tabular}

Source: own study

Table 6. shows percentage share of nonconformities occurring during hot-rolled plates production process in the fourth quarter of the year.

The data presented in Table 6 contains information about mass nonconforming plates $(\mathrm{Mg})$, and the percentages of each nonconforming plates.

Based on the data from Table 6, it was found that in the fourth quarter year were produced $12578.13 \mathrm{Mg}$ of nonconforming products.

Basing on data from the 6 Table the Pareto-Lorenz diagram was constructed (Fig. 5). 


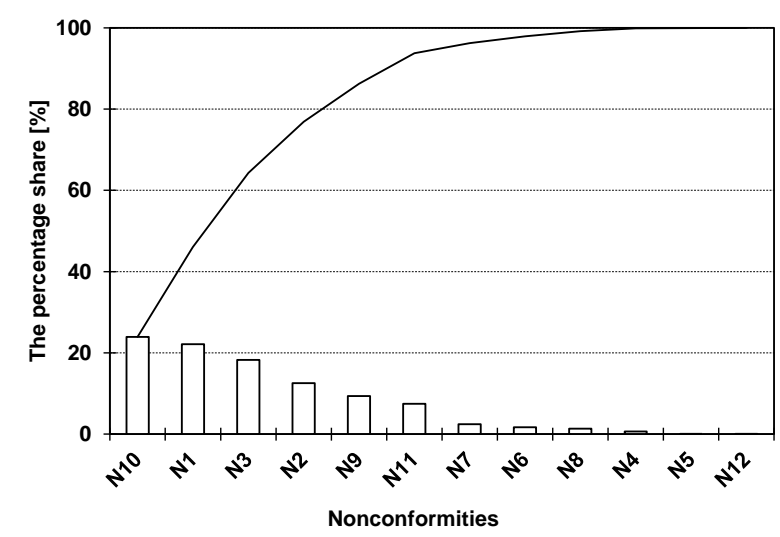

Fig. 3. The Pareto-Lorenz diagram for the nonconformities occurring during the production of hot-rolled plate $3^{\text {rd }}$ quarter of the year. Source: own study

Table 6. Percentage share of nonconformities occurring during the production of hot-rolled plates in the fourth quarter of the year

\begin{tabular}{|c|c|c|}
\hline \multicolumn{3}{|c|}{ IV QUARTER } \\
$\begin{array}{c}\text { Symbol of } \\
\text { nonconformities }\end{array}$ & $\begin{array}{c}\text { Amount } \\
{[\mathbf{M g}]}\end{array}$ & $\begin{array}{c}\text { The } \\
\text { percentage } \\
\text { share } \\
{[\%]}\end{array}$ \\
\hline $\mathbf{N}_{\mathbf{1 0}}$ & 4283.97 & 34.06 \\
\hline $\mathbf{N}_{\mathbf{1}}$ & 2562.66 & 20.37 \\
\hline $\mathbf{N}_{\mathbf{3}}$ & 2019.03 & 16.05 \\
\hline $\mathbf{N}_{\mathbf{2}}$ & 1190.45 & 9.46 \\
\hline $\mathbf{N}_{\mathbf{1 1}}$ & 946.40 & 7.52 \\
\hline $\mathbf{N}_{\mathbf{9}}$ & 889.09 & 7.07 \\
\hline $\mathbf{N}_{\mathbf{7}}$ & 259.96 & 2.07 \\
\hline $\mathbf{N}_{\mathbf{8}}$ & 194.70 & 1.55 \\
\hline $\mathbf{N}_{\mathbf{6}}$ & 158.40 & 1.26 \\
\hline $\mathbf{N}_{\mathbf{4}}$ & 58.01 & 0.46 \\
\hline $\mathbf{N}_{\mathbf{5}}$ & 12.77 & 0.10 \\
\hline
\end{tabular}




\begin{tabular}{|l|c|c|}
$\mathbf{N}_{\mathbf{1 2}}$ & 2.69 & 0.02 \\
\hline$\Sigma$ & 12578.13 & 100 \\
\hline
\end{tabular}

Source: own study

Based on the Table 6 and Figure 4, it could be stated that for over $70.48 \%$ of all detected nonconformities are responsible only $25 \%$ types of nonconformities. $70.48 \%$ of defects are connected with only three problems: cockles (two sides), interruption of metal and bad thickness whereas the remaining types of defects are merely $29.52 \%$ in total of all defect.

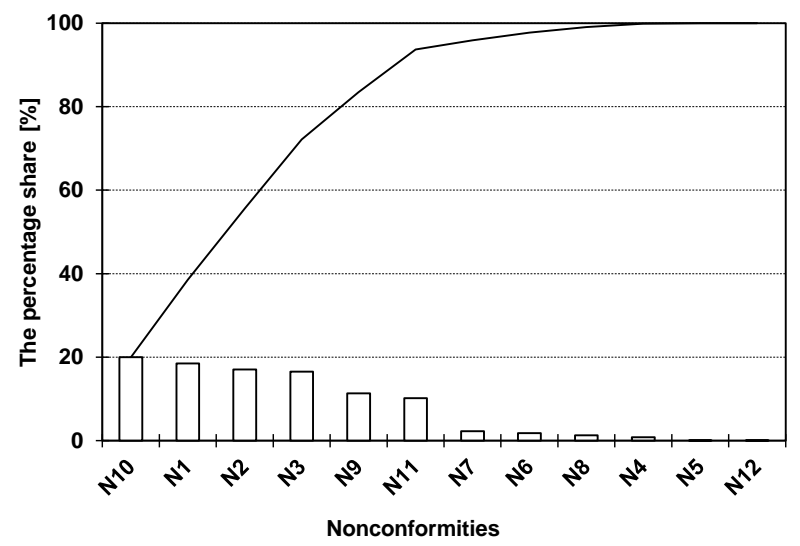

Fig. 4. The Pareto-Lorenz diagram for the nonconformities occurring during the production of hot-rolled plate $4^{\text {th }}$ quarter of the year.

Source: own study

Based on the of test results obtained, it was found that the most common causes that affect the nonconforming products, there are 3 nonconformities:

- Cockles (two sides) - Is related with a non-uniform deformation of the metal along the width during rolling. Local deformation causes a 
local elongation of the sheet. Wave is caused by excessive deflection rollers or badly matched by rolling method.

- Interruption of metal are due to poorly prepared ingot causing decrease in strength of sheet and its mechanical properties.

- Bad thickness is associated with bad calibration rollers.

The next step in the analysis of nonconformities is their number in each month of the year.

Based on Figure 5, it was found that the greatest numbers of nonconforming products were detected in October. Participation in the production of non-conforming plates amounted to $11.90 \%$. In August, October and November the share of nonconforming products ranged from $9 \%$ into $10.98 \%$. The smallest amount of nonconforming recorded in February, March and June, with the least result equal to $4.74 \%$.

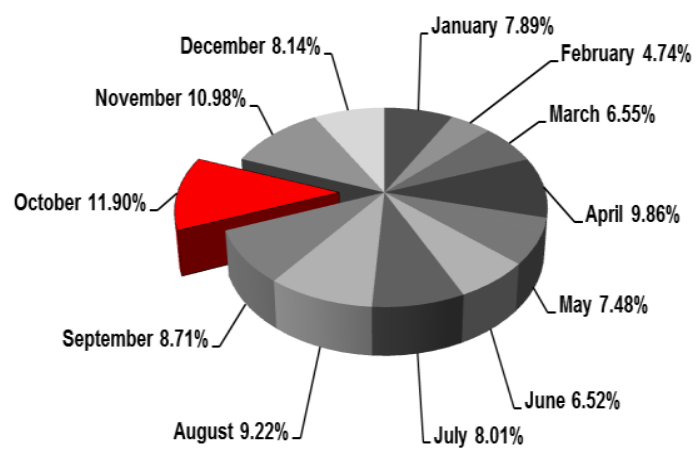

Fig. 5. The share of nonconforming products in the production of the hotrolled plates in the period under research.

Source: own study 


\section{Summary}

Chapter presents the results of research carried out in the mill plates. The aim of the study was to determine the level of quality hot-rolled plates for motor-car body.

The global market requires manufacturers to deliver the highest quality products. Quality is a determinant of customer satisfaction. Steelworks in Poland produce about 8 million tons of steel per year of which $90 \%$ used with for the production of hot-rolled products.

The results obtained allowed the identification of the main causes of non-conforming products. The rolling mill has big problems with the quality of the product. In the period of the share of non-conforming products was in the range $4.74 \%$ to $11.90 \%$. The total mass of nonconforming products amounted to 40882 tons. The analysis of 10 studies detected nonconformities. The greatest losses generate three problems: Interruption of metal, cockles (two sides) and bad thickness.

\section{Bibliography}

1. PN-EN ISO 2000:2006. Systemy zarzadzania jakościa. Podstawy i terminologia.

2. PN-EN 10149-3:2000.

3. BorkowsKi S.2004. Mierzenie poziomu jakości. Publisher Wyższa Szkoła Zarządzania i Marketingu in Sosnowiec. Sosnowiec.

4. BORKOWSKI S., UlEWICZ R. 2009. Instrumenty doskonalenia procesów produkcyjnych. Wyd. PTM. Warszawa.

5. DoBRZAŃSKI L. A. 2002. Podstawy nauki o materiatach $i$ metaloznawstwo. Materiaty inżynierskie $z$ podstawami projektowania materiałowego. Wydawnictwo Naukowo-Techniczne. Gliwice-Warszawa.

6. ULEWICZ R. 2003. Quality control system in production of the castings from spheroid cast iron. In: Metalurgija, Croatia. Vol. 42, Issue 1, pp. 61-63. 